\title{
Psychoanalysis and Translation: A Literature Review ${ }^{1}$
}

\section{(Psicoanálisis y traducción: análisis bibliográfico)}

Meritxell Serrano Tristán ${ }^{2}$

Universidad Nacional, Costa Rica

\begin{abstract}
The mutual implication of psychoanalysis with translation has produced a significant body of works that address the issue of subjectivity in the practice and teaching of translation. This paper traces this implication to the early beginnings of psychoanalysis, and reviews some of the most recent literature produced within translation studies.
\end{abstract}

\section{resumen}

La mutua implicación entre psicoanálisis y traducción ha llevado a un diálogo productivo que trata el problema de la subjetividad en la práctica y la enseñanza de la traducción. Este estudio analiza el origen de esta relación desde los inicios del psicoanálisis hasta la producción académica más reciente en el campo de la traductología.

Keywords: translation theory, psychoanalysis, translation choices

Palabras clave: teoría de la traducción, psicoanálisis, decisiones traductológicas

1 Recibido: 11 de febrero de 2014; aceptado: 22 de julio de 2014.

2 Escuela de Literatura y Ciencias del Lenguaje. Correo electrónico: meritxell.serrano@ gmail.com

$$
L_{\text {etras }} 56 \text { (2014), ISSN 1409-424X; EISSN 2215-4094 } 55
$$




\section{Introduction}

The interrelation between psychoanalysis and translation is not a new phenomenon. Sigmund Freud, the founder of psychoanalysis, occasionally compared his doctrine to translation, and the manifestations of the unconscious to a foreign language (Bass 102). In 1982, Meta published a special issue on psychoanalysis, and in 1998 TTR did the same. Both volumes were dedicated to the mutual implications between translation and psychoanalysis. Since then, many translation scholars and psychoanalysts have worked on amplifying the connections between these two fields of research and practice. The contention in most of these studies is that linguistic and cultural approaches to translation practice and theory fail to recognize a dimension always at play in textual production, the unconscious. Whether in slips of the tongue, transferential implications between translators, authors and texts, and linguistic choices, the unconscious is a constitutive component of text production. In what follows, this connection is going to be explored, first by providing a brief history of psychoanalysis and its approximations to language, then by reviewing the work of translation scholars pursuing this interrelation.

\section{Historical Background}

Developed in Vienna in the 1890s by Austrian neurologist, psychiatrist and physician Sigmund Freud (1856-1939), psychoanalysis is a theory and practice largely based on the hypothesis of the unconscious. In 1923, Freud defined psychoanalysis as (i) a method for investigating (unconscious) states of the mind, (ii) a method for the treatment of neurotic disorders, and (iii) a new scientific discipline derived from the psychological insights resulting from these methods ("Two Encyclopaedia Articles" 236). ${ }^{3}$

3 Due to the nature of this article (as a literature review), the bibliographical information may be found in the "References" section at the end of the article. 
The term "psychoanalysis" was first used in 1896, but in 1924, in an article prepared for the Encyclopaedia Britannica, Freud declared 1900 as the year in which psychoanalysis was born, and cites The Interpretation of Dreams, originally published in 1899, as the publication that presented the emerging field of study to the world ("A Short Account"191).

Initially perceived as a therapeutical technique based on hypnosis, psychoanalysis was intended to treat neurotic disorders (Fontana 27). These were the earlier years that led Freud and Josef Breuer to publish, in 1893, a preliminary report about hysteria, followed in 1895 by "Studies on Hysteria" [Studien Uber Hysteria] (1955). As Freud concludes in "Psycho-Analysis. The Libido Theory" [Psychoanalyse und Libidotheorie], two articles written more than twenty-five years later, two were the main results obtained in his and Breuer's early work: first, they had discovered that the symptoms affecting their patients meant something, had a meaning, and were in place of normal behavior; and second, they realized that when the meaning was discovered, the symptoms disappeared ("Two Encyclopaedia Articles" 235).

However, the first stages of psychoanalytical discovery soon led to a more complex understanding of the subject, an understanding that departed from the philosophical and psychological tradition of Western thought (Tubert 28) and "alienated [Freud] from the mainstream of contemporary psychiatry" (Gay 1).

What is so radically new and revolutionary about Freud's discovery? Certainly the notion of the unconscious was already in use when Freud began his work with Breuer. In the early $19^{\text {th }}$ century, philosophers such as Schopenhauer, Carus and Von Hartmann had already developed their own interpretations of the unconscious (Landman 53), and J. F. Herbart (1776-1841), a renowned German philosopher and educator who made important contributions to psychology, also recognized the existence of unconscious psychological processes (Strachey 156). In the 1870's, Pierre Janet (1859-1947), a French physician and psychologist, developed a thorough theory of 
dynamic psychiatry based on clinical data, a theory that highlights the notion of a "force that escapes consciousness and governs the activities undertaken by this consciousness" (Landman 55).

What makes Freud's discovery unique is, on the one hand, the speaking role assigned to the unconscious, a fact that is already present in Freud's earlier work. Lacan often underscored that "[r]ight from the outset, people failed to recognize the constitutive role of the signifier in the status Freud immediately assigned to the unconscious in the most precise and explicit ways" (Écrits: The First Complete Edition 426).

On the other hand, Freud's discovery consists of the unprecedented role ascribed to the unconscious in governing human behavior, thus displacing the all-powerful role of the ego. Freud was well aware of the implications of his discovery. In the conclusion to one of his introductory lectures to psychoanalysis, Freud himself compares his discovery of the unconscious to Copernicus' and Darwin's: the first revealed that the Earth was not the center of the universe, but a small fragment of a cosmic system; the second "destroyed man's supposedly privileged place in creation and proved his descent from the animal kingdomand his ineradicable animal nature" ("Introductory Lectures" 284). These three discoveries signal an unprecedented change in the history of science, thought, and perception.

The discovery of the unconscious in psychoanalytical terms represents a "third and most wounding blow from the psychological research of the present time which seeks to prove that the ego is not even master in its own house, but must content itself with scanty information of what is going on unconsciously in its mind" ("Introductory Lectures" 285). By literally displacing "the center of the human world from consciousness to the unconscious" (Felman, Jacques Lacan 64), what is at stake in Freud's theory is "not so much the scientific consequence of the change of center as the scientific process of decentering, that is, a new mode of reflexivity" (idem.). In other words, a new way of thinking and doing. 
In fact, Freud did more than establish a metaphysical entity: he described and showed what the unconscious is, how it works, and how it differs from the rest of the mental categories. Along this line, he developed the foundations for a solid theory and practice of the unconscious: the assumption that there exists an unconscious; the acceptance of notions such as resistance and repression in human behavior; a particular understanding of sexuality; and the preeminence of the Oedipus complex in the psychic life of humans. These are the foundations of psychoanalytical theory, which together with its technique (i.e. a particular take on language, free association, the interpretation of dreams, lapses and other parapraxes) represented a break away from mainstream therapeutical treatment and scientific research in Freud's historical context.

Although psychoanalysis was first met with indifference among the scientific community, it later aroused a "particularly violent opposition" ("A Short Account" 200), as described by Freud:

But in thus emphasizing the unconscious in mental life we have conjured up the most evil spirits of criticism against psychoanalysis... We psycho-analysts were not the first and not the only ones to utter this call to introspection; but it seems to be our fate to give it its most forcible expression and to support it with empirical material which affects every individual. Hence arises the general revolt against our science, the disregard of all considerations of academic civility and the releasing of the opposition from every restraint of impartial logic. ("Introductory Lectures" 284)

These reactions did not deter psychoanalysis from developing into an international movement, and "[f]rom the year 1902 onwards, a number of young doctors gathered around me with the express intention of learning, practicing and spreading the knowledge of psychoanalysis" ("On the History" 25), among them Otto Rank.

In 1909, Freud and Carl Jung were invited to give a series of lectures at Clark University in Worcester, Massachusetts. It was Freud's 
first opportunity to speak on psychoanalysis in public ("On the History" 36). During these lectures, psychoanalysis was represented by three men, besides Jung and Freud: Sándor Ferenczi, Ernest Jones, and A. A. Brill, who was already a practicing psychoanalyst in New York (idem.). Freud also became acquainted with James J. Putnam, a professor of Neuropathology at Harvard University, who having originally expressed "an unfavorable opinion of psychoanalysis" had then become a strong supporter and recommended psychoanalysis to the scientific community (idem.). In 1911 Havelock Ellis found evidence that psychoanalysis was being practiced not only in Austria and Switzerland, but in the United States, England, India, Canada and Australia ("A Short Account" 201). Moreover, the Zurich School of Psychiatry helped, in many ways, spreading psychoanalysis beyond European boundaries ("On the History" 27).

In 1920, The International Journal of Psychoanalysis, intended especially for readers in England, made its appearance under the editorship of Ernest Jones; and the Internationaler Psychoanalytischer Verlag, with its corresponding English company, the International Psychoanalytical Press, initiated a series of analytical publications under the name of Internationale Psychoanalytische Bibliothek (International PsychoanalyticalLibrary)(Freud, "AShortAccount"201).

Parallel to a geographical and institutional expansion of psychoanalysis came a widened field: "psychoanalysis extended from the field of the neuroses and psychiatry to other fields of knowledge" ("On the History" 40). For example, in Jokes and their relation to the unconscious (first published in 1905), Freud applies the analytic mode of thought to the problems of aesthetics ("On the History" 42); and in Totem and Taboo (first published in 1914), he makes:

an attempt to deal with the problems of social anthropology in the light of analysis; this line of investigation leads directly to the origins of the most important institutions of our civilization, of the 
structure of the state, of morality and religion, and, moreover, of the prohibition against incest and of conscience. (idem.)

EduardHitschmann(1871-1957), aphysician, and Alfred Robert von Winterstein (1885-1959), a philosopher, were the first to apply psychoanalysis to philosophical systems and personalities, although, to Freud, their initial conclusions were in need of both "extended and... deeper investigation" (idem.).

In his often quoted "return to Freud," the French psychoanalyst Jacques Lacan (1901-1981) continued to transform psychoanalysis from a purely therapeutic methodology into a "new form of knowledge about the different cultural and social realities" (Pombo 69). Lacan's return to Freud's original texts is an attempt to free psychoanalysis from "dogmatic, oversimplified interpretations, and [...] its inaccurate translations" (Felman, Jacques Lacan 54), and revitalize the theory and practice of the unconscious. His work consists not only of a historical return to the origin of a school of thought, but also and foremost, of an effort to reveal "a deeper logic at work in Freud's texts, a logic which endows those texts with a consistency despite the apparent contradictions" (Evans 68).

Lacan's take on Freud also signals a "linguistic turn" originally inspired by the anthropological work of Claude Lévi-Strauss (Evans 68). By borrowing such linguistic concepts as the sign, the signifier and the signified, and the distinction between langue and parole from linguistics (ibid. 102), Lacan uncovered "the linguistic basis of human subjectivity" (ibid. 154).

However, Lacan's interest in the traditional objects of humanities did not stop here: he was also self-consciously literary, producing endless forms of word play, puns and neologisms in his lectures, constantly interjecting philological commentary and giving papers on writers such as Marguerite Duras, Edgar Allan Poe and James Joyce. This interest earned Lacan the label of "worker in language" 
which Dennis Porter, a practicing psychoanalyst and theoretician, justifies in what he finds when reading Lacan's work: "Almost all of Lacan's writings and teachings are in one way or another a mediation on language, either in its function as constitutive of the unconscious and the human subject or, in the analytic encounter itself, as speech addressed to another." (1067)

This trend, however, was already present in Freud's work, where:

one out of three pages presents us with philological references, one out of two pages with logical inferences, and everywhere we see a dialectical apprehension of experience, linguistic analysis becoming still more prevalent the more directly the unconscious is involved" (Lacan, Écrits: A Selection 150).

In fact, Lacan would often contend that his return to Freud was nothing more than a repetition of what was already present in Freud's work: "What I have just said has so little originality... that there appears in it not a single metaphor that Freud's works do not repeat with the frequency of a leitmotif' (qtd. in Felman, Jacques Lacan 54).

Thus, Lacan focuses increasingly on language. Not surprisingly, Louis Althusser would define Lacan's return to Freud as "an exemplary lesson of reading, the effects of which [...] go well beyond its original object" (qtd. in Felman, Jacques Lacan 19). For Felman, who has published extensively on the relationship between psychoanalysis and literature, Lacanian psychoanalysis provided a new understanding of the very nature of interpretation, and modified "the possibilities of reading by drastically transforming the procedures, strategies, and techniques available for the interpreter" (ibid. 19).

Traditionally, however, this transformation first led to a form of applied psychoanalysis that in many ways betrayed the very nature of Freud's discovery. A literary critic and psychoanalyst herself, Felman undertakes a revealing study of psychoanalytical critics analyzing Edgar Allen Poe's poetry and fiction, and condemns the all-too-easy 
equation of art with the psychological truths of the creator. In her study, Felman found that literary critics were seeing Poe's literature as a means to trace "[his] art to an abnormal condition of the nerves" (Krutch qtd. in Felman Jacques Lacan 34). Such is the case in Marie Bonaparte's influential study, Edgar Poe: Étude psychanalytique (published in 1933, with a prefatory note by Sigmund Freud), a study that, in Felman's view, "sets out primarily to diagnose [Poe's] sickness and trace the poetry to it" (ibid. 36). By reducing poetry to a clinical reality, applied psychoanalysis fails to recognize the challenges proposed by psychoanalytical discourse.

Bonaparte's tradition of applied psychoanalysis has carried on into our times. In his work Out of my system: psychoanalysis, ideology and critical method, Frederick Crews contends that in "[u]sing psychoanalytic assumptions a critic can show how a writer's public intention was evidently deflected by a private obsession... Or again, he can draw biographical inferences on the basis of certain recurrent themes that the author hadn't consciously meant to display" (168)

Breaking from the tradition of applied psychoanalysis, Peter Brooks' essay "Freud's Masterplot: Questions of Narrative" (1980) provides a useful illustration of the interest in reading psychoanalytical texts through the lens of literature. Fighting the notion of "psychoanalysis as a stable master discourse that may treat a text as an unmediated record of a particular psyche," Brooks claims "that there can be a psychoanalytic criticism of the text itself that does not become - as has usually been the case - a study of the psychogenesis of the text (the author's unconscious), the dynamics of literary response (the reader's unconscious), or the occult motivations of the characters (postulating an 'unconscious' for them)" (Brooks 299).

This approach is shared by influential scholars such as Shoshana Felman (1982, 1983, 1985, 1987, 1992, 1993, among others) and Geoffrey Hartman (1985), whose works explore the implications (and complications) between psychoanalysis and literature. In the preface to Psychoanalysis and Literature, a collection of essays that 
includes Brooks' essay mentioned above(1980), Felman contends that "literature has been for psychoanalysis not only a contiguous field of external verification in which to test its hypotheses and to confirm its findings, but also the constitutive texture of its conceptual framework, of its theoretical body." (9) Instead of using psychoanalysis as an authoritative body of knowledge to subordinate literature - to interpret and explain it - these critics advance the notion of a real dialogue between the two bodies of knowledge and language. The interpreters are no longer called upon "to apply to the [literary] text an acquired science, a preconceived knowledge" but "to explore... to articulate the various ways in which the two domains do indeed implicate each other" (idem.).

\section{Translation and Psychoanalysis}

Somewhat parallel to the implication between literature and psychoanalysis is the incidence of psychoanalytical theory in translation studies. As Andrew Benjamin points out in his article "Translating

Origins: Psychoanalysis and Philosophy," "there is more involved here than a simple connection or interrelation since translation figures from the start within psychoanalysis." (18) Indeed, the metaphorical interconnection between these two activities was first established by Sigmund Freud himself, who often compared psychoanalysis to translation and the unconscious to a foreign language (Bass 102-103).

The two special issues published in 1982 and 1998, the first by Meta and the second by TTR, signal the insertion of psychoanalysis into translation studies. Both volumes were dedicated to the mutual implications between translation and psychoanalysis.

Historically, however, both practicing psychoanalysts and translation scholars have participated in a dialogue between their corresponding fields of study. This dialogue takes different forms, which can be grouped under three general categories: first, scholars whose work uses translation as a tool or metaphor in understanding the nature 
of psychic realities, and its implications for psychoanalytical theory and practice; second, scholars whose work studies the implications of psychoanalytical findings for translation theory and practice, in an attempt to improve our understanding of translations and account for the subjectivities involved in the process; and third, the body of studies on the translation of psychoanalytical texts. This paper will address the first two categories, i.e. translation as a tool or metaphor in understanding the nature of psychic realities and the implications of psychoanalytical findings for translation theory and practice. The third category ${ }^{4}$ will not be addressed in this paper.

\section{Translation in Psychoanalytical Theory}

In regards to the first group, i.e. scholars whose work reflects on translation as a tool for psychoanalytical theory and practice, let us mention the work by Patrick Mahony (1982), Andrew Benjamin (1989, 1992), JeanLaplanche (1992) and Esther Peeren (2004), among others.

In "Towards the Understanding of Translation in Psychoanalysis," a paper first published by the Journal of the American Psychoanalytic Association and later included in Meta's special issue, Patrick Mahony argues the case for "Freud's historical eminence as one of the great thinkers and innovators in the domain of translation" (63), and offers a detailed survey of the notion of translation in the Freudian corpus, which, in his view, "reveals its comprehensive scope and its value of giving an imposing coherence to seemingly disparate phenomena." (64) For Freud, Mahony argues, neuroses, symptoms, the analyst's interpretation and the movement of psychic material are all forms of translations, whereas repression is theorized as a failure in translation (idem.).

In "Psychoanalysis and Translation," a chapter in his book Translation and the Nature of Philosophy (1989), Andrew Benjamin

4 For a sampling of materials see Arich-Gerz 2006, Hall 2005, Mahony 2001, Gray 1992, Bass 1985. 
follows a similar approach by recounting the uses of the word "translation" in Freud's writings, and the relationship between thesereferences and the structure of signification that emerges within psychoanalysis. Benjamin focuses on two particular uses of the term: "the first sense pertains to the action of the analyst; the analyst as a translator... The second sense concerns translation as an element of psychic life." (136) As an element of psychic life, Benjamin notes that in Freud's texts,

translation operates on two levels: first, "the manifest content is a translation of the latent content"; and second, "the interpretation of the manifest content involves its translation into the language of consciousness." (145) These two levels of translation bring up interesting questions that Benjamin is willing to pursue: if the manifest content is already a translation, what is the original (for psychoanalysis)? Or more precisely, what constitutes the text of the original? Moreover, if translation has already taken place in the latent text, what, then, gets translated?

It must be noted that although Benjamin discusses the notions of original and equivalence for translators, his goal is not to dwell on these questions but to reflect on the nature of psychoanalytical theory. At stake in his discussion is the structure of signification that emerges in psychoanalysis, and the construction of a narrative in consonance with Freud's discoveries, a narrative that "no longer depend[s] upon the recovery or retrieval of either an archaic meaning or an origin of meaning" (Benjamin 6). As Benjamin also suggests, "what emerges as central to these present concerns is the description of the analyst as translator and the activity of translation as moving from the language of fantasy to a general language" (ibid. 144). These metaphorical comparisons invariably question the status of original and translation-a status often taken lightly in today's language industry.

Jean Laplanche's use of translation as a category of analysis departs from the current trend in classical psychoanalysis. In his lecture, "Psychoanalysis, Time and Translation," given at the University of Kent in 1990, Laplanche refuses to see the notion of interpretation in 
the analytic method as a translation of the present into the past. Basing his reasoning on Freud's own "refusal to yield to the temptations of "psychosynthesis"" (171) — understood as the tendency of analysts to recast a synthetic vision of their patients - Laplanche understands the analytic method through the analogy with a process of de-translationthat is, a reversion of translation (note that in Laplanche translation does not involve different language systems). For him, the "analytic interpretation consists in undoing an existing, spontaneous and perhaps symptomatic translation, in order to rediscover, anterior to the translation, what it so ardently wished to translate and possibly to permit a 'better' translation; that is to say, one that is more complete, more comprehensive and less repressive." (170)

Esther Peeren (2004) discusses the work of Mikhail Bakhtin and Jean Laplanche to contend that in both authors, "the subject is conceived as emerging through intersubjective translation." (1) In Bakhtin, translations are used as a theoretical category of the humanities, since they involve "establishing, transmitting and interpreting the words of others" (qtd. in Peeren 357). In Laplanche, translation is used as a theoretical category of psychoanalysis. Whereas the Bakhtinian subject is perceived as containing both a domestic and a foreign remainder (a 'semi-translation') (5), for Laplanche there is either full translation or no translation at all: "Laplanche's unconscious thus takes the shape of [...] obstruction, which interferes between the self and its self-consciousness." (7) Peeren concludes that both theorists turn the subject into a translator, and conceptualize translation as transformation (11).

\section{Psychoanalysis in Translation Studies}

Further efforts have been undertaken by different translation scholars using psychoanalytical concepts to explain translation theory and practice, and account for the effects of the unconscious in the assembly of the target text (our second category mentioned above). 
This scholarship ranges from illustrating an aspect or question of translation by way of Freudian and Lacanian psychoanalysis, such as in Douglas Robinson (Who Translates?), to the implications of psychoanalytical discoveries for the process of translation and the effects of the unconscious in the target texts, such as in the work of Alan Bass, Dennis Porter, Rosemary Arrojo, Maria Paula Frota, Lawrence Venuti, Marta Marín i Dòmine, Anne Quinney, and Elena Basile. Their work shows different ways in which psychoanalytical thought has a contribution to make to the understanding and reading of actual translations, as well as to the development and enrichment of translation theories.

In "Translation and the Trials of the Foreign," Antoine Berman performs an analytic analysis of translation - a detailed examination of the system "of textual deformation that operates in every translation and prevents it from being a 'trial of the foreign'." (286) These forces, Berman argues, are largely unconscious, and form part of the translator's being: that is, translators cannot escape them, and their practice "must submit to analysis if the unconscious is to be neutralized" (idem.). Berman defines twelve tendencies of textual deformation, and provides examples for most of them. These tendencies produce "a text that is more 'clear,' more 'fluent,' more 'pure' than the original," leading Berman to conclude that such tendencies "are the destruction of the letter in favor of meaning." (297) However, Berman believes that translation should not be limited to simple meaning restitution, and should take on a formative role in language by laboring on the letter, that is, producing literal translations (attached to the letter of works). A translation that labors on the letter "restores the particular signifying process of works (which is more than their meaning) and transforms the translating language" (idem.).

Playing on Freud's Totem and Taboo, Douglas Robinson's Translation and Taboo (1996) draws from textual evidence dating back to the ancient mystery religions, well into the Christian era and the present, to locate a general taboo against translation. Robinson also 
introduces Lacan's concept of the unconscious as the "discourse of the Other," which he adapts to his discussion as "the Other-as-mystery" and "the Other-as-reason" to explain why the translation of sacred texts was taboo in the medieval church, and later banned altogether: "The Other-as-mystery would have been the force that once, in 'prerational' civilization, tabooed consciousness" (31) and created within itself "through repression or negation, its own rebellious or 'anarchistic' counterpart, the Other-as-reason" (idem.). The Other-as-reason "fosters belief in absolute communicability," whereas "the Other-as-mystery prefers the feel of a text, the intuitive, preverbal experience [...] The Other-as-reason prefers the sense of a text, and the sense is all you can translate with reliable equivalence." (37)

In Who Translates?, Robinson makes use of other Lacanian concepts such as the Schema L (in its simplified form) and its four terms (the subject, the other, the ego and the Other), to inform his inquiry into translator subjectivities. He opens the question of Otherness to illustrate the wide variety of voices that are conjured by the translator at work. He sets out to explore "the gray area between the translator as a rational, fully conscious subject who is completely in control of all his thoughts and actions... and the translator as a mystical void filled with other voices, a channel or medium for the speech of others." (11) In Chapter 5, "The Pandemonium Self", Robinson introduces Lacan's typologies of Otherness, which for him constitute an image of the Self that is conditioned by all the forces of Otherness: i) the invisible translator-subject; ii) the introjected people and tools involved in the translation process; iii) the translator's ego-ideals; and, iv) the translator's Other. Robinson's take on subjectivity rejects the long-standing rationalist tradition of Western thought given to the assumption of "an executive decision-maker called the mind or the intellect or reason, situated somewhere in the brain." (151) Robinson overcomes this understanding of mental work by way of the pandemonium self, conditioned as it is by thousands of agents or forces, including Lacan's notion of the Other (idem.). While Robinson 
makes a sound theoretical contribution to the notion of subjectivity in translation, his study does not provide examples to gauge the presence and effects of these voices.

In "Psychoanalysis and the Task of the Translator," Dennis Porter draws out some of the implications of Lacan's psychoanalytical findings in the work and theory of translation. After establishing the notions of translation advanced by Walter Benjamin and Paul de Man, Porter contends that Lacan's concepts of the Other and the Symbolic order sum up "the disjunction between individual human beings and the languages they speak and write." (1077) This constitutive disjunction, at the very root of subjecthood (or split subjectivity), implies a combination of "a radical sense of the impossibility of communication" with a belief in speech (ibid. 1081). And when it comes to communication between two languages, "although mis-translation may be all we have, it is far from the nothing that seems to be implied for the target language in de Man's affirmation of the 'impossibility of translation" (idem.). Porter sees in the near misses or "failures" of translation nothing but the effect of the unconscious - and it is only in listening or paying close attention to the 'failed achievements' that "we know each other and know ourselves." (1080)

Such errors or mistranslations are thus read as near misses or failed achievements that satisfy an unconscious wish. In Porter's words, although translation is possible, it is also a miscommunication between languages, since "we remain caught up in the network of signifiers that first constituted us and will always exceed our attempts at mastery." (1081) In spite of the theoretical relevance of this article, Porter does not provide translation examples to illustrate his arguments, thus limiting the scope of his study.

Of relevance to the often unexplored questions of ethics in translation, Amalia Rodríguez explores the questions of translator accountability in El saber del traductor: hacia una ética de la interpretación (1999). In her book, Rodríguez concludes that there is more to the translation process than the rational, conscious and 
self-conscious self of the translator. Thus, she proposes an ethics of translation that takes into account the psychoanalytical categories of desire and unconscious. Such an ethics would expect the translator to "account for his or her motivations, resources, desires, as a reader from whom we expect a very precise account of what he or she could or was able to read in a text" (25, my translation).

As subjects of the unconscious, translators must situate themselves within the order of language, and "recognize that language is already loaded with our entire history" (idem.). This history is precisely the knowledge or savoir of the translator: The messages we write or speak do not originate from a stable source - the source text-but emerge from a combination of the signifiers that represent us, and the signifiers of the languages we are working with. Moreover, Rodríguez contends that "If every utterance contains an axiology, the translator works with this, that is, with values, and must pay attention to the dialogic nature of every discourse, to its address to the other, to the ambivalence with which meaning emerges or imposes itself beyond the author's (declared or apparent, visible) intention." (266) Because of the translators' place in the universal discourse of the unconscious, they must account — and be held accountable - for all their decisions, successful or not.

In a line similar to Rodríguez's, Rosemary Arrojo seeks to account for the savoir of translators in the classroom setting. In Arrojo's view, what future translators need to learn is the overall politics of truth that "determines the mechanisms that control the production, distribution and evaluation of 'originals' and their translations." (145) These "politics of truth" are also behind the choice of translator: the variables that lead to commission a project to one translator or translation agency as opposed to another. Immersed in the intricacies of producing, distributing, and evaluating translations, translators must learn to write. Learning to write means, above all, learning to take responsibility for the decisions made during the translation process, and to recognize the limitations that such a responsibility imposes on 
the work of translators. In other words, as a writer, the translator needs to recognize that his or her translation choices can never be free "since they are always produced within power relations and associations, in which the role of the translator is that of an active member and agent of change" (Arrojo 146).

As agents, future translators must learn to write, that is, to be the "author" of the text to be translated. In order to do this, future translators "must make explicit, and understand, the transferential relationship that links them to the text and to its 'original' author," as well as to their professor of translation in the classroom setting (Arrojo 145). In the same line taken by Rodriguez, Arrojo contends that in accepting responsibility for their decisions regarding the meaning of the text, and their translation solutions, translators accept "the impossibility of their freedom." (146)

Maria Paula Frota's work goes a long way to show the presence of unconscious effects in target texts. Her book $A$ singularidade na escrita tradutora (2000) opens a theoretical dialogue between translation studies, linguistics and psychoanalysis, and explores their different approaches to language. After an extended discussion of Lawrence Venuti's work and a review of scholarly work on the mutual implication between translation and psychoanalysis, Frota explores the singularity of the translator's writing, where she follows up on Freud's understanding of errors and verbal slips, and expands these to include the singularities of translation.

Two articles expand on her original research. In "The Unconscious Inscribed in the Translated Text," Frota contends that although much is being done in translation studies to fight against the invisibility of translators, the efforts of most contemporary theories "have concentrated on a subjectivistic notion of the subject." (2) In Frota's view, this notion promotes the belief "in the author as a free or autonomous individual whose own reason is the sole origin of his work" (idem.), whereas psychoanalysis, since its inception, has insisted that "the ego is not even master in its own house, but must content itself with scanty 
information of what is going on unconsciously in its mind" (Freud, “Introductory Lectures" 285). This idea runs parallel to Arrojo's notion of translation as writing, and the limitations such a practice entails.

Frota wants to address "a sphere that is necessarily implied in the act of translating: the unconscious" ("The Unconscious" 2). To do so, she focuses on misreadings and slips of the pen which are in turn interpreted as effects of the unconscious inscribed in the (translated) text. In accord with Freud's postulates, these verbal slips carry information "often unknown to the person producing them" (ibid. 6). Although these verbal slips are "undeniably a mistake," as they bring about a radical break with what is established or predictable, there are "subjective verbal choices that [...] do not [...] disrupt the code so drastically as to result in complete nonsense" (ibid. 9). These subjective choices or "singularities," as Frota calls them, are forms that escape dichotomies,

so as to be neither correct nor incorrect, correct and incorrect, effects of an intellectual secondary elaboration invaded by the unconscious... These forms would indeed consist of formations of the unconscious, but less explicit, more subtle, perhaps due to the fact that the unconscious is only partly successful in its struggle against repressive forces. (ibid. 9)

Frota then analyzes a student's translation of a poem by Sylvia Plath, "Kindness." The student translator chooses to translate the prepositional verb 'picking up' as 'colando'(glueing), in the following context:

$[\ldots]$

Sugar is a necessary fluid,

Its crystals a little poultice.

O kindness, kindness

Sweetly picking up pieces! (ibid. 10) 
When asked to justify her choice, which at first sight seemed inappropriate to Frota, the student referred to a scene from her childhood in which her mother, when baking cakes, would say to her that "the glue of the cakes was the icing," and in fact when cake was crumbling into pieces due to the softness of the dough, "with a bit of patience and with the help of the icing, the restoration of the cake was possible" (ibid. 10). As can be seen from this example, the student's choice is not the most predictable literal translation for "picking up" but in justifying her (unconscious) choice, the translator develops a network of signifiers that gives her choice a place in the structure of the poem. Frota does not explain how to differentiate a simple moto-sensorial error from errors caused by unconscious motivations. However, in this regard, we need to be reminded that psychoanalysis ensues from the premise that the unconscious is always engaged in speech, because the unconscious is language. Therefore, moto-sensorial errors are never void of (potential) meaning.

In her article "Erros e lapsos de tradução: un tema para o ensino," Frota investigates different types of translations, beginning with Anthony Pym's distinction between mistakes (binary errors) and errors (non-binary errors). After considering non-binary errors as possible subjective variations or acceptable translation decisions, Frota considers binary errors - translation choices that are unquestionably wrong - as the equivalent of verbal slips. Following Freud's discoveries in The Psychopathology of Everyday Life (first published in 1901), Frota understands these verbal slips to be effects of unconscious thoughts or desires that are in permanent struggle with conscious intentions. In her view, these errors are not produced by mere inattentiveness on the translator's part but by the insisting force of unconscious material (154).

Binary errors can be produced either during the reading process of the source text, or the writing process of the target text. During the reading process, translators may, for example, read a word wrongly due to the effect of a verbal bridge ("Erros e lapsos" 152), a concept 
developed by Freud to signify the material similarity between signifiers that gives rise to slips of the pen. Or the translator may be fully understanding the source text, and produce a slip of the pen in the target text, again due to a verbal bridge. To illustrate this type of error, Frota gives the example of a verse from one of Walt Whitman's poems, "In you I wrap a thousand onward years", which had been translated as "Em voces contenho mil lágrimas progressivas" (meaning, "In you I wrap a thousand progressive tears") (Silveira qtd. in Frota "Erros e lapsos" 152). The visual similarity between 'years' and 'tears' served as a verbal bridge that produced a slip or binary error, thus emphasizing the role of the unconscious in translation choices. Frota does not explain these errors in terms of the translator's unconscious motivations, since she is aware that such an understanding can only be achieved through individual analysis. It is still valid, however, to call such errors a product of unconscious forces, whether the reader is able to uncover their motivations or not, since psychoanalytical theory has extensively shown that the unconscious uses such strategies to emerge.

Lawrence Venuti explores the effects of the unconscious in translation in his paper "The Difference that Translation Makes: The Translator's Unconscious." In this article, Venuti delves into ways in which the unconscious "might operate in the translator's choices and be visible in the translated text, available for reconstruction." (215) Instead of using psychoanalysis as his point of departure, Venuti suggests looking at translation theory itself. In this sense, Venuti contends that the difference translation makes can be seen as a loss-loss of intratextual effects and intertextual relations, loss of context, loss of the materiality of the signifier — and a gain — proliferation of semantic possibilities through a different signifying chain, creation of textual effects, different meanings, structures, figures and traditions "that go far beyond the establishment of a lexicographical equivalence." (219) Venuti calls these textual effects "the remainder," following the work of linguist Jean-Jacques Lecercle. The remainder directs attention to 
"the utter heterogeneity of language", thus "complicat[ing] the communication of a univocal signified" (idem.). According to Venuti, "In a translation, the remainder consists of linguistic forms and textual effects that simultaneously vary both the current standard dialect of the translating language and the formal and semantic dimensions of the foreign text" (idem.), and can be both intentional (as in compensation, explicitation, etc.) and unintentional (as in a verbal slip).

Among the translation errors Venuti introduces to illustrate the remainder, we have a misconstruction of the French syntax in Alan Bass's translation, Writing and Difference (1978). The sentence in French, "Quand elle réinstitue un corps, elle est poésie", which in a close English version would read "When it [reinstitutes] a body, it [translation] is poetry," is rendered by Bass as "And when that materiality is reinstated, translation becomes poetry" (Venuti 220). Among the different departures from the French, Venuti focuses on "the replacement of the indefinite article 'un' with the demonstrative adjective 'that', whereby 'that' evidently refers to the materiality of the foreign text mentioned in the first three sentences of the passage." (221) In trying to determine the cause of this error, Venuti rules out "sheer incompetence" and lists some of Bass's qualifications that make him a competent academic and knowledgeable translator of Derrida. Venuti then concludes that there is more at stake than a mere oversight: Bass's translation reverses Derrida's assertion about untranslatability. In Venuti's view, this misconstruction needs to be understood symptomatically "as a signifier that is unconsciously motivated." (222) In other words, it is Bass's "desire that the foreign text be fully translatable" (223) which makes its way into the target text.

We need to note here how Venuti personalizes the misconstruction or verbal slip in the translation, and traces its origin to a single cause: the translator's "repressed interpretation of the foreign text" (Venuti 220). That is, Venuti's hermeneutic move fixes the meaning of the translation slip as if the critic had access to the translator's dynamic history and psychic life. Our approach here, however, intends 
to follow a different route. First of all, as Frota suggests, only the subject uttering a verbal slip can identify the cause or motivation (even when this cause or motivation may seem incomplete, shifting, changing, unfinished). Second, the effects of the unconscious do not represent the existence of a coherent, empirical and internal reality, such that would allow us to locate the "hidden" ideas, emotions and intentions, and thus rid the subject of all forms of repression. The unconscious is a complex concept that can be better understood in terms of Robinson's Pandemonium self.

Other translation scholars, such as Elena Basile and Anne Quinney, have made attempts at using psychoanalytical categories to explore both the translation process and the end-product. In this regard, Basile is interested in "the more elusive and less visible aspects of the translation process $[. .$.$] aspects which resist being readily slotted$ within one or another of the translator's consciously assumed ideological stances" ("Most Intimate Act" 1). In this first paper, she conducts a psychoanalytical exploration of the role played by the unconscious to "explain the libidinal economies of translation" (ibid. 2).

In a later article, "Responding to the Enigmatic Address of the Other: A Psychoanalytical Approach to the Translator's Labour," Basile draws from psychoanalyst Jean Laplanche's configuration of the unconscious as an "à traduire" (to be translated), and his interpretation of the "scene of seduction" to question the intimate dynamics of reading/ writing the other that comes into play in the work of translators. Basile equates the scene of translation with the originary scene of seduction, by which "the enigmatic message of the adult is unwittingly 'implanted' in the child before s/he can make any sense of it," thus becoming an "'internal other' that addresses the subject from within, and remains charged with a drive "to be translated"" ("Responding" 15). The scene of the translation thus parallels the originary scene of seduction, triggering the "subject's internal other," whose presence can manifest through the subject's choices, behaviors and symptoms. The relevance of this theoretical framework for the analysis of literary translation is, simply 
put, to establish the translator's affective dynamics and, potentially, to understand "the singularity of his/her choices" (ibid. 16).

To illustrate this, Basile looks at a Canadian feminist experiment in collaborative translation first published in 1989. The project was undertaken by the members of Tessera's editorial collective and consisted of a sequence of English translations of a French poem by Lola Lemire Tostevin. Each translation is accompanied by a brief commentary, where the translator explains her own working process and decisions. Basile compares these translations and reflects upon the commentaries. In one of her reflections, she notes the first translator's choice to render the verse "espaces vers / vers où?" for "green spaces tending to what / or where?", which signals "how the aural resonance of "vers" (in French "vers" is pronounced exactly like "vert": "green", and "ver": "worm") had affective precedence over its semantic valence, a precedence that could only partially be resisted (in that she playfully left out "the earthworms") ("Responding" 22). The words "vert" and "ver" are not present in the poem, but the acoustic resemblance causes the translator to consider "tending to," "green" and "worm" as potential equivalents of "vers," finally settling for "green" and "tending to." This example signals "the complex affective posture engendered by the potentially conflictual relation between desire and the constraint of fidelity in translation" (idem.). In the translator's view, "translation [...] will always leave a record of misreadings which are more or less accidental. I say "more or less" because I tend to err in the direction of meanings I desire" (Knutson qtd. in Basile, ibid. 22).

In her study, Basile encounters a tendency, on the translators' part, to emphasize "a complex temporal relation between the impact of the poem and the awareness of what drew her to specific verbal choices" (ibid. 22). These choices do not always "come from a space of conscious will, but tend to "happen" in moments of affectively charged attention, which precede, and to some extent displace, the translator's conscious desire for mastery over semantic effects" (idem.). To conclude, Basile remarks that "In these practices 
translation functions as a dialogical and open-ended process of response-ability towards a perceived "à traduire" rendered visible in one's own language by the triggering impact of the "à traduire" of the language of the other" (ibid. 26).

The psychoanalytical categories explored by Anne Quinney's paper on "Translation as Transference: A Psychoanalytic Solution to a Translation Problem" are transference and resistance. In her paper, Quinney turns her attention to the experience of the translator, who is subject to the power inscribed in his or her relationship to the author, to the target language and to the culture attached to this language, not to mention the relationship of translator to the text, to the audience, to the publisher and to the reviewers in the target language." (112) Psychoanalysis is thus advanced as a tool to understand the hierarchy that exists between translator and text or translator and author (idem.).

Therole ofpsychoanalysis in translationis presented byreference to Antoine Berman's work on the "analytic of translation" which "calls for an analysis of textual deformation as an inescapable byproduct of the translator's unconscious desires"(Quinney 112). Quinney expands upon Berman's work to contend that the unconscious "functions in active and determining ways on the lexical, syntactical and structural choices the translator makes in the course of translating a text." (113) Toillustrate this, Quinney highlights a problem she encountered while translating J. B. Pontalis' memoir entitled Fenêtres into English. After self-analyzing her own difficulty understanding a source passage, and consulting with the author (who also happens to be a practicing analyst), Quinney discovers the source of the problem that prevented her from reconstructing a syntactical structure about father substitutes: she was resisting the very idea of father substitutes - "that is, that one might even seek a substitute for the father." (114)

The difficulty she encounters in rendering a syntactically simple French structure in English may be taken as a symptomatic behavior that expresses the translator's unconscious resistance to the meaning of a sentence, and replays "the struggle [...] known as the Oedipal 
drama." (111) According to Pontalis, this was not an instance of a momentary lapse in concentration, but a moment of parapraxis on the translator's part. Following Freud, Quinney asserts: 'the text 'rouses' the reader's defenses - some information or imputation distressing to him - and which is therefore corrected by being misread so as to fit with a repudiation or the fulfillment of a wish." (115)

Marta Marín -Dòmine's study, Traduir el desig: psicoanàlisi $i$ llenguatge is perhaps the most recent study in book form on the implications of psychoanalytical theory for translation. Similar to the previous theorists, Marín-Dòmine explores language-and language work-based on the assumption that in every discourse there exists a double textuality: the linguistic discourse and the unconscious discourse. Because the discourse of the unconscious is largely the subject of psychoanalysis, and since psychoanalytical practice is already a practice of translation, its methodology allows for a specific understanding of both source and target texts, and of the process of translation.

Traduir el desig elaborates on the concepts of the unconscious, desire and the primacy of the signifier as developed by Sigmund Freud and Jacques Lacan. The first part of the book introduces the reader to the psychoanalytical postulates on the function of language. The second part explores the notions of truth, meaning and style, which in Marín-Dòmine's view have been traditionally perceived differently in translation and psychoanalysis. To the notion of meaning (sentit) as a univocal entity of speech, psychoanalysis opposes the notion of signification, which results from the primacy of the signifier over the signified, and its relation to other signifiers (102). Finally, MarínDòmine appends to the notion of style, as defined by rhetoric, the notion of jouissance, which refers to the libidinal economy of the subject of the unconscious (idem.), a concept also explored by Basile.

To illustrate the proposed application of the psychoanalytical methodology to the practice of reading in and for translation, MarínDòmine compares the translation intoEnglishofa passage fromMiguel 
de Unamuno's Niebla (160). In the passage chosen by Marín-Dòmine, the translator renders the adjective "augusta" (referring to the main character of the story, Augusto) as "exalted pose;" and " $E s t a b a$ tan elegante, tan esbelto, plegado y dentro de su funda!" (referring to the main character's umbrella), as "Didn't it look beautiful and slim, elegantly folded, and in its cover?".

Upon analyzing the translator'schoices and justifications, MarínDòmine concludes that her decisions were based on presuppositions alien to the source text, but which nonetheless affect the construction of the target text. Had the translator 'listened to the surface of the text' she would have found the existing intratextual connections between the name 'Augusto,' and the adjective 'augusta' (161), as well as the intertextual reference to the figure of August the Emperor (162). In her view, and following a psychoanalytical reading of the signifier and its associations to other signifiers, the translator could have opted for a more literal rendering of the term, i.e. "august," and thus have preserved the intratextual connections. This intratextuality is also suspended by rendering 'esbelto' as 'beautiful,' since the metonymic reference to known statues of August the Emperor is lost; and by the explicitation of the subject of that second phrase, an explicitation that erases the ambiguity of the source text.

In Marín-Dòmine's view, "this passage clearly exemplifies a translation approach that, aimed at recovering the 'profound' meaning of the text, ignores the law of the signifier and, in the end, fails to see... that the letter is in full view, constituting a body with the word and offering a signification embedded in the very surface of the text" (162, my translation). Although it is questionable to what extent Marín-Dòmine's suggestions are "more appropriate" or "less subjective" than the translator's choices, what remains true is that, at least in two of these instances (the adjectives 'augusta' and 'esbelto'), the translator made a choice amongst other options (in the case of the pronoun 'it,' the translator had less of a choice). 
Marín-Dòmine's proposed methodology, not only for the translation process, but for the process of reading both source and target texts, is what in Lacanian terms is known as "floating attention" (escolta flotant) (ibid. 163). This methodology, used in the analytical situation, prompts analysts to abstain from understanding the analysand's discourse and fixing the meaning of his or her utterances. Instead, analysts are encouraged to pay attention to the non-meaning of these utterances, and listen to sounds, phonemes, words, expressions, loose phrases, pauses and parallelisms, among others, in an attempt to make the analysand reflect upon his or her utterances - and henceforth the issues at stake. When applied to translation, the translator is being asked to respect the material aspect of the word (the signifier) privileged by the author and to opt for a more literal rendition of the source text. According to Bernard This and Pierre Thèves, quoted in Marín-Dòmine, when the translator tries to recover the meaning of a text, he or she ends up imposing, by way of metaphor-that is, by way of the use of equivalents - a meaning that often has more to do with his or her own point of view than with what is implicit in the source utterance (163-7).

It is questionable to what extent this psychoanalytical approach can be fruitful when applied to translation practice. While Lacanian psychoanalysis holds that "the pursuit of meaning leads to the further alienation of the subject in the Other's meaning and the Other's desire" (Fink 88) and thus needs to be avoided in the analytical setting, the role of the translator consists, to some extent, in punctuating meaning, fixating meaning in its nonetheless continuous sliding. Also, we need to keep in mind that Lacan's notion of the "incessant sliding of the signified under the signifier" (Lacan, Écrits 419) does not imply that there is no discernible signified of a signifier: "Lacan does not proceed as if we cannot truly interpret psychoanalytic texts... because we cannot be sure of what they mean" (Fink 88). Translators must learn to decide what words mean, and choose a way to express that 
meaning in the target language - thus the risk involved in translating and interpreting texts, since we cannot avoid saying (and doing) our share in the reconstruction of the target text.

\section{Concluding Remarks}

The common denominator among these psychoanalytical approaches to the subject in translation is the question of an operation that escapes the (conscious) control of the translator. For these scholars, the work of translators implies the coherent and unforeseeable irruption of unconscious effects that take shape in the translation process and product. Each of their studies sets out to explain or demonstrate that the work of translation does not escape these effects; that near misses, errors or misconstructions, as well as translation problems, are not accidental, and create a discourse parallel to the translated discourse. For them, these verbal slips originate, to a large extent, in unconscious forces, desires or thoughts.

The unconscious is thus understood as a universal category that lies beyond the translator's cognitive grasp, and which acts surreptitiously in the process of reading and interpreting the source text and producing a target text in at least four different stages:

1. Choosing the source text to be translated (Basile)

2. Reading and interpreting the source text to produce a target text (Frota, Quinney).

3. Relating to the authors during the translation process (Quinney, and to some extent Basile).

4. Relating to the power hierarchies of clients (including teachers) and readers (Robinson, Arrojo, Frota, Quinney and Basile).

5. Producing the target text (most of the authors reviewed).

Upon recognizing the unconscious as a universal category, these authors move on to identify psychoanalytic hypotheses in the translation 
process and product. Some of these hypotheses are transference, resistance, Oedipal drama, defense mechanisms, the signifier, the Other and repression, all of which account for the subject in psychoanalytical terms. Basile, for example, highlights the affective precedence over semantic valence of translation choices, while Quinney discusses her own difficulty to understand a segment of a text in terms of the Oedipal drama. Frota distinguishes between binary and non-binary errors, and equates the latter with verbal slips, open to interpretation. She also speaks of the translator's singularities as implicit manifestations of the unconscious in the target text; these singularities do not necessarily break with what is established or predictable in the target language. Venuti, on the other hand, develops the notion of "unintentional remainders" as errors that "may reverberate with meanings that amount to a repressed interpretation of the foreign text" (Venuti 220). Marín encourages a distinction between metonymic and metaphoric translation to highlight the importance of reading to the letter and avoiding subjective interference in the production of target texts.

Overall, the process of writing the target text is perhaps the area that has attracted most attention in the search for unconscious effects, and has certainly produced the most verifiable data. Examples are nonetheless scarce, and studies aimed at producing new data are in order.

\section{References}

Arrojo, Rosemary. Tradução, descontrução e psicanálise. Rio de Janeiro: Imago, 1993. Print.

Bass, Alan. "On the History of a Mistranslation and the Psychoanalytic Movement." Difference in Translation. Ed. Joseph F. Graham. London: Cornel UP, 1985. 102-141. Print.

Benjamin, Andrew. "Translating Origins: Psychoanalysis and Philosophy." Rethinking Translation: Discourse, Subjectivity, Ideology. Ed. Lawrence Venuti. London: Routledge, 1992. 18-41. Print. 
Basile, Elena. "Responding to the Enigmatic Address of the Other: A Psychoanalytical Approachh to the Translator's Labour." New Voices in Translation Studies 1 (2005): 12-30.

"The Most Intimate Act of Reading: Affective Vicissitudes in the Translator's Labour." Doletiana 1 (2004): 1-7.

Berman, Antoine. "Translation and the Trials of the Foreign." The Translation Studies Reader. Ed. Lawrence Venuti. London: Routledge, 2000. 284-297. Print.

Brooks, Peter. "Freud's Masterplot: Questions of Narrative." Literature and Psychoanalysis-The Question of Reading: Otherwise. Ed. Shoshana Felman, ed. Baltimore: Johns Hopkins UP, 1980. 280-300. Print.

Crews, Frederick. Out of My System: Psychoanalysis, Ideology and Critical Method. New York: Oxford UP, 1975. Print.

Evans, Dylan. AnIntroductory DictionaryofLacanian Psychoanalysis. New York: Routledge, 1996. Print.

Felman, Shoshana. Jacques Lacan and the Adventure of Insight: Psychoanalysis in Contemporary Culture. Cambridge MA: Harvard UP, 1987. Print.

. The Literary Speech Act: Don Juan with J. L. Austin, or Seduction in Two Languages. Trans. Catherine Porter. Ithaca, New York: Cornell UP, 1983. Print.

. Literature and Psychoanalysis: The Question of Reading-Otherwise. Baltimore: Johns Hopkins UP, 1982. Print.

. What Does a Woman Want? Reading and Sexual Difference. Baltimore: Johns Hopkins UP, 1993. Print.

. Writing and Madness (Literature/Philosophy/Psychoanalysis). Trans. Martha Noel Evans and Felman. Ithaca, New York: Cornell UP, 1985. Print.

Felman, Shoshana, and Dori Laub. Testimony: Crises of Witnessing in Literature, Psychoanalysis, and History. New York: Routledge, 1992. Print. 
Fink, Bruce. Lacan to the Letter: Reading Écrits Closely. Minneapolis: U of Minessota P, 2004. Print.

Fontana, Cristina. Todo lo que usted nunca quiso saber sobre el psicoanálisis. Madrid: Síntesis, 2001. Print.

Freud, Sigmund. "Introductory Lectures on Psycho-Analysis: Fixation to Traumas. The Unconscious." Trans. James Strachey. The Standard Edition of the Complete Psychological Works of Sigmund Freud. Vol. XIV. London: The Hogarth Press and the Institute of Psycho-Analysis, 1963. 273-285. Print.

. "The Ego and the Id." Trans. James Strachey. The Standard Edition of the Complete Psychological Works of Sigmund Freud. Vol. XIX. London: The Hogarth Press and the Institute of Psycho-Analysis, 1961. 2-66. Print.

. "Negation." Trans. James Strachey. The Standard Edition of the Complete Psychological Works of Sigmund Freud. Vol. XIX. London: The Hogarth Press and the Institute of PsychoAnalysis, 1961. 235-239. Print.

. "On the History of the Psycho-Analytical Movement."

Trans. James Strachey. The Standard Edition of the Complete Psychological Works of Sigmund Freud. Vol. XIV. London: The Hogarth Press and the Institute of Psycho-Analysis, 1957. 1-66. Print.

. "A Short Account of Psycho-Analysis." Trans. James Strachey. The Standard Edition of the Complete Psychological Works of Sigmund Freud. Vol. XIX. London: The Hogarth Press and the Institute of Psycho-Analysis, 1961. 189-209. Print.

. "Studies on Hysteria." Trans. James Strachey. The Standard Edtion of the Complete Psychological Works of Sigmund Freud. Vol. II. London: The Hogarth Press and the Institute of Psycho-Analysis, 1955. Print.

. "Two Encyclopaedia Articles: Psycho-Analysis. The Libido Theory." Trans. James Strachey. The Standard Edition of the Complete Psychological Works of Sigmund Freud. Vol. 
XVIII. London: The Hogarth Press and the Institute of PsychoAnalysis, 1955. 233-259. Print

. "The Unconscious." Trans. James Strachey. The Standard Edition of the Complete Psychological Works of Sigmund Freud. Vol. XIV. London: The Hogarth Press and the Institute of Psycho-Analysis, 1957. 159-215. Print.

Frota, Maria Paula. "Erros e lapsos de tradução: un tema para o ensino." Cadernos de traduçaõ 17.1 (2006): 141-156. PDF file. . A singularidade na escrita tradutora: linguagem e subjetividade nos estudos da tradução, na lingüística e na psicanálise. Campinas SP: Pontes, 2000. Print.

"The Unconscious Inscribed in the Translated Text." Doletiana 1 (2004): 1-11.

Gay, Peter. "Sigmund Freud: Psychoanalyst." Time 29 Mar. 1999. Web. 16 Jan. 2008.

Gray Ornston, Darius, ed. Translating Freud. London: Yale UP. 1992. Print.

Hartmann, Geoffrey H. ed. Psychoanalysis and the Question of the Text. Baltimore: The Johns Hopkins UP, 1985. Print.

Lacan, Jacques. Écrits: The First Complete Edition in English. Trans. Bruce Fink. New York: Norton, 2006. Print.

. Écrits: A Selection. Trans. by Bruce Fink. New York: Norton, 2002. Print.

Landman, Patrick. Freud. Trans. Marta Sánchez-Eguibar. Madrid: Edicions Istmo, 1999. Print.

Laplanche, Jean. "Psychoanalysis, Time and Translation." Seduction, Translation, and the Drives. Eds. John Fletcher and Martin Stanton. London: Institute of Contemporary Arts, 1992. 161177. Print.

Mahony, Patrick. "Towards the Understanding of Translation in Psychoanalysis." Meta 27.1 (1982): 63-71. PDF file.

Mahony, Patrick.. "Freud and Translation." Imago 58.4 (2001): 837840. PDF file. 
Marín-Dòmine, Marta. Traduir el desig: Psicoanàlisi i llenguatge. Barcelona: Eumo Editorial, 2004. Print.

Peeren, Esther. "The Subject as Translator: Mikhail Bakhtin and Jean Laplanche." Doletiana 1 (2004): 1-12.

Pombo Sánchez, Manuel. "Actualitat del llegat del Dr. Sigmund Freud." Aloma 20 (2007): 67-81.

Porter, Dennis. "Psychoanalysis and the Task of the Translator." Modern Language Notes 104.5 (1989): 1066-1084. PDF file. Quinney, Anne. "Translation as Transference: A Psychoanalytic Solution to a Translation Problem." The Translator 10.1 (2004): 109-128.

Robinson, Douglas. Translation and Taboo. DeKalb: Northern Illinois $U P$, 1996. Print.

.Who Translates? Translator Subjectivities Beyond Reason. Albany: SUNY UP, 2001. Print.

Rodríguez Monroy, Amalia. El saber del traductor. Spain: Montesinos, 1999. Print.

Strachey, James. "Nota introductoria." Obras completas: Sigmund Freud. Vol. XIV. Buenos Aires: Amorrortu, 1976. 156. Print.

Venuti, Lawrence. "The Difference that Translation Makes: The Translator'sUnconscious." Translation Studies: Perspectives on an Emerging Discipline. Ed. Alessandra Riccardi. Cambridge: Cambridge UP, 2002. 214-241. Print. 